\title{
Waiver of Jurisdiction
}

\section{An Evaluation of the Process in the Juvenile Court}

Douglas A. Sargent, M.D.

Director, Child Study Clinic, Wayne County Juvenile Court, Detroit, Mich., Assistant Clinical Professor, Department of Psychiatry, Wayne State University College of Medicine

Psychiatrist, Federal Reformatory for Boys, Chillicothe, Ohio, 1958-55 B.A., 1946, Brown University; M.D., 1950, University of Michigan Medical School

Donald H. GoRdon

Professor of Law, Wayne State University

Partner, Slater and Goldman, Boston, Mass., 1949-56

B.A., 1946, Brown University; LL.B., 1948, LL.M., 1957, Harvard Law School

A critical evaluation of the waiver process identifies certain inconsistencies between the goals and methods of the juvenile court movement and points out the difficulties resulting from procedures that attempt to reconcile the goals of punishment and rehabilitation. Several popular explanations for the use of the waiver process are examined and found insufficient to justify removing children from the jurisdiction of the juvenile court. Other motives for the waiver process are offered for consideration. The juvenile court movement is seen as an experiment in criminal justice, and the waiver process as a safety valve for the release of community pressures which threaten the experiment. The juvenile who is waived becomes the target for the court's frustrations and the scapegoat upon whom the accumulated guilt of the community is piled. A dispassionate reconsideration of the waiver process in the light of the issues raised may lead to its abandonment.

$\mathbf{I}^{\mathbf{n}}$ MOST states the juvenile courts and the adult criminal courts have concurrent or overlapping jurisdiction in matters concerning youthful offenders. ${ }^{1}$ In certain cases the juvenile court may waive jurisdiction over such offenders so that they may be tried in the adult courts. Generally the authority to waive jurisdiction

${ }^{1}$ In fourteen states jurisdiction is concurrent in the cases of all children. In twentythree states jurisdiction is concurrent for varying age spreads-e.g., Illinois, ten years and over; Michigan, fifteen years and over; California, sixteen years and over. resides in the judge of the juvenile court. $^{2}$

- Guides to when that discretion should be exercised are usually not provided. For example, the Michigan statute (Probate Code, ch. 712-A, Compiled Laws of 1948, \& 4) says: "In any case where a child over the age of 15 years is accused of any act the nature of which constitutes a felony, the judge of probate of the county wherein the offense is alleged to have been committed may, after investigation and examination, including notice to parents if address is known, and upon motion of the prosecuting attorney, waive jurisdiction; whereupon it shall be lawful to try such a child in the court having general criminal jurisdiction of such offense." 
In this paper we shall explore the function of the authority to waive jurisdiction, the criteria which appear to be involved in its exercise, and the implications of waiver for the theory of juvenile court procedure.

\section{Criminal Law and Social Utility}

Whatever its genesis (in religion or social utility), the criminal law is normative; it assumes that, by and large, the people whose conduct is to be judged are capable of observing the standard which it sets up, or that they can become capable if they wish to do so. In short, it assumes free will. On the other hand, modern psychology holds that a person's freedom of choice is sharply circumscribed by his biological nature and his social experience.

Turning from norm to sanction, we run into still another conflict. Why do we punish? The answer has fallen into two broad categories. ${ }^{3}$ On the one hand, the intuitive or moral judgment is that wrongdoing should be followed by pain visited on the wrongdoer, who ought to be made unhappy just because he has done wrong. ${ }^{4}$ On the other hand, the utilitarian judgment is that obedience to the law ought to be encouraged and disobedience discouraged in order to create a more desirable society, ${ }^{5}$ rather than

${ }^{8}$ We ought not to forget that in respect to society's treatment of the criminal, punishment by the state is relatively a newcomer. F. Pollock and F. W. Maitland, History of English Law (Boston: Little, Brown, 1899), p. 449.

- This, of course, oversimplifies the basis of the "retributive theory" of punishment. For a careful analysis of the various approaches see A. C. Ewing, The Morality of Punishment (London: K. Paul, Trench, Trubner, 1929) .

s Included in this category are the "deter. rent" and "reformative" theories of punishment. Obviously, if punishment is designed to vindicate some moral, intuitive, or religious judgment.

The confusion about both the "whence" of law and the "why" of punishment, arising from the attempt to reconcile free will with determinism, ${ }^{6}$ has created problems in the administration of criminal justice, which attempts simultaneously to protect society and to reform or rehabilitate the prisoner, to punish him for wrongdoing and to deter others from committing the same wrongs. Although the juvenile court movement was based on the conviction that the standards and methods and punishment of the criminal courts were not suitable for the young offender, the juvenile courts have inherited the ambiguities which run through criminal law generally.

One may see the position of juvenile courts on these issues more clearly by looking at procedures involving concurrent jurisdiction with adult criminal courts-specifically, the use of waiver of jurisdiction.

\section{Reasons Given for Waiver}

Each of the reasons frequently given for waiver could stand as a paradigm for the kind of non sequitur into which the judge is led by the law's uncertainties.

1. One of the arguments offered is that some children are really not children:

The court recognizes that while it has a responsibility to do everything possible

merely to hurt the criminal, there is no need to be concerned about its effect on him beyond making sure that it is sufficiently painful.

- See Jerome Hall, Studies in Jurisprudence and Criminal Theory (New York: Oceana, 1958), pp. 270-271. Cf. Michael and Wechsler, Cases and Materials on Criminal Law (New York: Oceana, 1958), pp. 8, 17-18. 
for a child, there may be some children so mature that the facilities of the juvenile court cannot aid them and their cases must be transferred to the criminal courts. 7 (Italics added.)

This reasoning presents several difficulties. First of all, what test can be applied to a person of juvenile years to determine that he has reached maturity? And what is meant by maturity, as it is used here? Size? Physical appearance? These attributes vary greatly among children, especially at puberty. There is no fixed relationship between size and degree of physical maturation. Appearance may suggest a rough estimate of a child's state of physical development, but it is deceptive; more important, it is beside the point. The gap between bodily development and mental or emotional maturity may be wide, and it is the latter that is relevant here.

How is a court to test a child's emotional maturity? By the nature of his crime? This is a poor test because every kind of crime committed by children fifteen to seventeen years old is also committed by younger children. Are there any other tests-perhaps psychological or psychiatric examinations-which can tell the court that a child has reached maturity? If they exist, are they used? How reliable are they?

The diagnostic tools of the psychiatric clinic are not designed to provide answers to these questions. When the clinician evaluates a child's emotional maturity his reference is a scheme of personality development according to which most persons (of whatever age) who commit crimes are in some significant respect emotion-

${ }^{2}$ Advisory Council of Judges and National Council of Juvenile Court Judges, Guides for Juvenile Court Judges (New York: National Council on Crime and Delinquency, 1957), pp. 5-6. ally immature. The diagnostic method, then, begs the question and is worthless for this specific legal purpose.

Perhaps tests might be devised which would compare the emotional maturity of the child criminal with that of a hypothetical "average" adult criminal, but such a test has yet to be framed and the comparison would be of questionable value. In any case, it is doubtful that competent clinicians could be found who would be willing to devise a test whose purpose was to find out whether a child is "mature" enough to be tried in criminal court and be sent to prison. Many clinicians believe that, in view of the present state of our penal system, no adult, let alone a child, should be sent to prison.

2. Another argument frequently given for waivers is that certain cases are "hopeless." It runs something like this: "The juvenile court's job is to rehabilitate. This child before the court is still immature, but, though we have done all we can do for him, he is a hardened criminal, beyond rehabilitation. Therefore his case should be handled by the criminal court."

It is true that in many instances the child's antisocial behavior results from a personality disorder so deep-seated and fixed that it seems untreatable. Age alone is not a reliable criterion of untreatability, since some disorders are as likely to resist treatment at age six or twelve as they are at fifteen. If chance of salvage, rather than age, is to be the basis for deciding whether juvenile courts retain jurisdiction over a child, then some children twelve or even younger would have to be "waived." Here we reach the point at which this criterion for waiver becomes absurd, for few thoughtful people could stomach 
sending children of such tender years to prison.

Further, if the "hopeless" label is pinned to a child because he has failed to respond favorably to the rehabilitative measures that have been applied to him, we must assess the adequacy of these measures so that we can determine what confidence we can have in the accuracy of this label.

In most juvenile courts the attempt at rehabilitation consists of a quick (and often inadequate) diagnosis of the child's social problems, followed by a court disposition aimed at solving those problems. Sometimes the diagnostic phase is fleshed-out with a psychiatric evaluation, the conclusions of which the court may or may not follow. First offenders and younger children may be dismissed with a warning despite indications of serious disturbances underlying the surface behavior. Others may be piled on to a probation caseload already so large that the officer can give each probationer only a few minutes of supervision a week, or they may be removed from their homes and sent to institutions for rehabilitation. And some children who need the services of remedial institutions but cannot get in because of overcrowding are placed in foster homes under the theory that any home at all is better than the miserable homes in which they were raised. The trouble with this practice is that, in general, such foster home placements are not supervised adequately and the children cannot be helped sufficiently with their problems for the placement to work out.

This, then, is the rehabilitative effort, the failure of which has earned the child the appellation, "untreatable." It would be more accurate and honest to say that treatment of a kind likely to succeed has never been tried, that the makeshift substitutes for adequate treatment have not been effective, and that the juvenile court, having run out of things to do with, for, or to the child, would like the criminal court to try its hand at solving the problem. The logic behind this kind of waiver-if treatment doesn't work, punishment will-is obscure.

3. Still another reason given for waiver is "the lack of facilities." It goes this way: "The child before the juvenile court is immature and seems to be salvageable by methods known to the court. But he is dangerous and facilities in which to contain him during the treatment process are not available to juvenile court. Therefore the child should be tried in criminal court."

While more straightforward than Argument No. 2, this approach to the jurisdictional problem raises questions of logic and utility. It assumes that the criminal court has available to it the treatment or other rehabilitation facilities which the juvenile court lacks.

The alternatives open to criminal courts are few. The sentencing judge can fine the malefactor, place him on probation, or commit him to the custody of the correction department. Since the juvenile court judge can order restitution and can place the offender on probation, this leaves only the various penal institutions to accomplish the rehabilitative job that the juvenile court says it is not able to do.

The only thing a prison can do well is keep prisoners under lock and key. If the avowed purpose is rehabilitation or treatment, one can hardly imagine a more useless place than a prison. The concept of incarceration and the means by which penal insti- 
tutions achieve it undermine the reclamation of distorted human lives. Traditional sentencing, which narrowly defines the length of incarceration, is itself antithetical to the goal of rehabilitation. It does not prescribe the length of treatment in accordance with the degree of personality disorganization and the length of time needed to effect a change in the criminal. Instead it usually attempts to "make the punishment fit the crime" in a blatantly retributive fashion. All attempts at rehabilitation in prisons are frail grafts on a punitive organism; they do not thrive on this hostile substrate.

Anyone familiar with prisons knows that the weakest-which usually means the youngest-prisoners are victimized by the strongest, the most innocent by the most depraved. Thus the child who is sent to prison is likely to be the target of every "wolf" inside the wall. If he does not succumb to this assault, he may be driven, out of selfdefense, to become even more aggressive than he was when he entered. Most prisons do attempt to segregate the more hardened inmates from those less confirmed in criminal ways, but this is seldom effective enough to protect the fifteen-year-old. And, finally, the penal system's minimum security institutions or prison camps can hardly, if logic is respected, be deemed suitable for the child who has been waived out of the juvenile court because he is dangerous and a security risk.

If the juvenile court cannot find within its purview the means to rehabilitate children and to contain them during the treatment process, it is futile to look to the criminal courts for help. When the juvenile court washes its hands of a child, it throws him on the scrap heap of prison and it gains nothing by employing euphemisms to describe this tragedy. On the contrary, it loses a great deal. As long as the juvenile court practices the self-deception that allows it to believe in the existence of facilities "elsewhere," it will not face squarely the need to develop for itself the tools it requires to care for these children.

\section{Other Motives}

These reasons given by juvenile courts for waiving jurisdiction do not appear to us to stand up well under scrutiny. But they are not the only reasons, and they may not even be the strongest ones (for judges are not -at least by nature-notably illogical). We suggest that two other reasons, not usually expressed out loud, underlie the decision to waive jurisdiction.

The first of these may be labeled "Protect the Experiment at All Costs"; it could be articulated as follows: When children commit crimes of violence or sexual aggression, strong community pressure is brought to bear on the judge to send the child to criminal court. The judge-who, after all, is only a human being and, in some states, may be made an ex-judge by the electorate-is not always able to resist this pressure.

Community voices which urge that such children be tried as adults frequently emphasize the alleged inadequacy of the juvenile court to deal with dangerously aggressive youngsters. The juvenile court is accused of being "soft on children," an accusation which its judges, for obvious reasons, are loath to refute. (Should they say, "No, we're hard on children!"?) The critics imply that the criminal court is better able to handle the dangerous child, which claim can be true only if that court holds the 
child-criminal before it to be expendable and gives him a life sentence, thus removing him permanently from society. However, criminal courts are not likely to deal out such sentences except for murder (and murder is a crime that is not apt to be repeated if the criminal regains his liberty. ${ }^{8}$ ) Since prisons neither rehabilitate these children nor remove them forever from society, but, instead, rely on the experience of prison to "teach them a lesson," this method reduces itself to simple retribution. Further, since the lesson prisons teach best is how to be a better (i.e., more effective) criminal, this method is a very dangerous one. Society and its judges know this; at least, they have had ample opportunity to learn it.

Yet judges continue to send children to prison. Why?

We suggest that the juvenile court system is an experiment in criminal justice, an experiment in which society, perhaps without realizing it, has a great stake. Judges, on the other hand, are aware of the shortcomings of systems by which society protects itself from its criminals, and they look to the juvenile court experiment to produce more effective methods. The community, in general not yet convinced of the value of the experiment, is unwilling or unable to give up totally the satisfaction of punishing wrongdoers in exchange for the dubious advantage of rehabilitating them, and its thwarted desire for retribution builds up a head of pressure that threatens to destroy the juvenile court system. ${ }^{9}$

${ }^{8}$ C. H. Growdon, A Group Study of Juvenile Homicide (Columbus, Ohio: State Bureau of Juvenile Research, Dept. of Public Welfare, 1949).

- See Joseph N. Ulman, "The Trial Judge's Dilemma-A Judge's View," in Sheldon Glueck, ed., Probation and Criminal Justice
The waiver process offers the juvenile court judge a safety valve through which to vent this pressure. From time to time, as occasion demands, it sacrifices the more flagrant offenders. Thus the community's need for retribution is satisfied and the juvenile court experiment is able to proceed unscathed.

The second of the hidden motives might be called "The Scapegoat Effect": The child who is selected for waiver is more than only the sacrifice that ensures the continuation of the juvenile court experiment; he is also the community's and the court's scapegoat. He is singled out as the object upon whom everyone can fix blame.

Society erects legal barriers against only those acts that are likely to be committed. With these laws we prohibit the expression of impulses common to everyone, although the lawabiding citizen may not be aware of the presence of such impulses within himself. He need look no farther than his own dreams (or his thoughts when a few cocktails have loosened his inhibitions) to discover that what the criminal does is not entirely foreign to his own nature.

If he were to look at himself so dispassionately, the results would be painful and guilt-provoking. Partly to avoid such unpleasant introspection society raises a hue and cry against criminals. Their apprehension, conviction, and punishment allow us to convince ourselves that the blame and guilt lie on the criminal and not within ourselves. With his punishment we expiate our own guilt. Were this not so, we would have discarded punishment long ago as an illogical and ineffective method of preventing

(New York: Macmillan, 1933), pp. 109-132, for an analogue in the sentence problem in adult criminal courts. 
crime and protecting society against its criminals. We need to punish them for our own sake, irrespective of the effect this has on the criminal.10

Judges and juvenile court workers, like other members of society, have their own problems in this regard. In the face of endless provocation to hit out at children whose flagrant exhibitions of unrestrained instinctual impulses anger him, the juvenile court worker stays his hand. Bolstered by his dedication to the ideal of treatment, he attempts to winnow out and discard punitive measures. This nonpunitive attitude is extremely difficult to maintain, because it comes into conflict with the anger the child stirs up within him. He may be secretly outraged at the child for getting away with practices which he himself has had to relinquish in his own life. In addition, the most stable, mature person may find his control over his own unconscious, primitive urges ithreatened by the seductive spectacle of another person indulging in taboo practices. ${ }^{11}$ Added to this is the resentment produced by the accumulated frustrations imposed upon the dedicated court worker through the failure of the community to provide him with facilities adequate to the task of rehabilitation. The child who has acted in such a way as to be eligible for waiver may become a convenient target for the court worker's accumulated wrath.

At the waiver hearing the child is faced with the probation officer whose hand of friendship and help the child seems to have rejected. Evidence is displayed which shows the child's ap-

\footnotetext{
${ }^{10}$ Ruth S. Eissler, M.D., "Scapegoats of Society," in Searchlights on Delinquency (New York: International Universities Press, 1949), pp. 288-305.

${ }^{11}$ This is one rationale for laws against pornography.
}

parently willful disregard for the court's past efforts to save him from his waywardness. However carefully, gently, even inspirationally the judge may voice his decision to waive, the culprit is made to feel the full weight of responsibility for his failure to profit from his encounter with the juvenile court. It is made clear that the child, and not the system, has failed. He is stripped of his childhood and, at the conclusion of this ceremonial handwashing, turned over to the criminal court.

\section{Playing It Straight}

We have purposely simplified this account of the waiver process in order to highlight elements which often are obscured by the juvenile court's more obvious and genuine regret at having failed to salvage the child. We believe that juvenile courts generally are unaware of these elements of revenge and displacement of guilt onto the child, which pass unnoticed in the excitement that attends the waiver process. Nevertheless, we suggest that precisely these unconsciously motivated elements produce effects that account for many of the inconsistencies and ambiguities of juvenile court procedure. Perhaps they may be responsible for some of the "treatment" failures, too.

We know that a central problem for many delinquent children is their mistrust of authority and their rejection of the behavioral standards imposed on them by authority figures. Such attitudes are often produced by unfair, inconsistent, or even dishonest handling by parents earlier in the lives of these children. If these distorted attitudes toward rules and the people who make them are to be corrected, the correctional agent must present to these children a reliable 
and convincing image of unshakable honesty and forthrightness. Without this basic requirement, all the therapeutic skill and ingenuity in the world will not make a dent in their problems. If the juvenile court tells its charges that "we're here to help you, not to punish you," and at the same time unwittingly undermines this stand through procedures that suggest a lack of sincerity, the chances of successful rehabilitation are materially reduced.

\section{Eliminate Waiver}

What conclusions can be drawn from this exploration of juvenile court procedures that relate to waiver of jurisdiction?

First, we have shown that certain practices of the court are antithetical to its manifest commitment to a policy of protecting and rehabilitating children. We have suggested that this ambivalent attitude springs from unconscious conflicts within society and its members, including court representatives. We hope that bringing these conflicts into the arena of conscious scrutiny will make them susceptible to a rational evaluation and, eventually, a logical solution.

Second, we have emphasized what appears to be the inadequacy of the means currently employed to rehabilitate wayward children and the futility of the waiver process as a method of furthering the rehabilitative effort. We hope that our voices, added to others, will help to secure the facilities juvenile courts need for doing a proper salvage job on the wrecked lives of their wards.
A careful inspection of the waiver process emphasizes for juvenile courts the urgency of re-evaluating their methods and developing the adequate facilities and understanding required to care for these children. ${ }^{12}$ We are convinced that such review and development would lead to the gradual elimination of the waiver of jurisdiction by juvenile court judges.

${ }^{12} \mathrm{Cf}$. the following statement from U.S. Children's Bureau in cooperation with NCCD and National Council of Juvenile Court Judges, Standards for Specialized Courts Dealing with Children (Washington, D.C.: U.S. Govt. Printing Office, 1954), pp. 27-28: "It is recognized that there may be some-very few-juveniles, 16 years or older, who because of their personality and stage of social and emotional development do not benefit from training school programs designed for the treatment of adolescent children. If these few children repeatedly commit acts at the institution which are felonies or certain specified limited types of misdemeanors (i.e., simple assaults and malicious destruction of property) and, if these acts are disruptive of the institution's program or harmful to others in the institution, then some provision should be made for a procedure under which these facts could be brought to the attention of the specialized court. If the court should then find these facts to be true, that efforts to treat such children have failed, and that no other resources exist in the community through which the necessary treatment can be secured, then the court should be able to waive jurisdiction over such children to the criminal courts with respect to those specific acts committed at the institution. This procedure is suggested only on the assumption that every effort has been made to develop at these institutions the best possible treatment facilities. These safeguards have been suggested, for inclusion in specific terms in the law, as a means of insuring that this procedure will not become a substitute for the fullest development of resources and facilities for the treatment of children involved in delinquency." 